\title{
Food Insecurity, Quality of Life, and Diet Optimization of Low Income University Students in Selangor, Malaysia
}

\author{
Roslee Rajikan $^{1 *}$, Lee Hui Shin ${ }^{1}$, Nurul Izzati Abdul Hamid ${ }^{1}$, Siti Masitah Elias ${ }^{2}$ \\ ${ }^{1}$ Dietetics Program, Faculty of Health Sciences, Universiti Kebangsaan Malaysia, \\ Kuala Lumpur 50300, Malaysia \\ ${ }^{2}$ Financial Mathematics Program, Faculty of Science and Technology, Universiti Sains Islam Malaysia, \\ Nilai, Negeri Sembilan 71800, Malaysia
}

\begin{abstract}
This study aim to determine the relationship between food security with quality of life and nutritional status among low income students in a public university in Selangor, Malaysia. A cross-sectional survey was carried out on 108 low income students who were chosen by convenient sampling method. Students were interviewed using a structured questionnaire to obtain information on their sociodemographic characteristics, food security status, quality of life, anthropometric data, and dietary intake. Results showed that $69.4 \%$ of students were food insecure with $50 \%$ reported low food security and $19.4 \%$ with very low food security. For quality of life, students scored highest in social relationship domain $(68.60 \pm 14.53)$ while lowest in physical health domain $(53.87 \pm 10.42)$. There was no significant association between food security and quality of life, ethnic, age, family income, financial assistance, CGPA, and food expenditure ( $p>0.05$ ). Majority of students $(59.2 \%)$ had normal Body Mass Index (BMI), followed by $20.4 \%$ were overweight, $10.2 \%$ were obese, and $10.2 \%$ were underweight. There was no significant correlation between nutritional status with food security status ( $p>0.05)$. To estimate the minimum daily food expenditure to fulfil all nutrient requirements, an optimum diet model was created by using linear programming model. Result showed that the minimum price of one day menu for male and female student was USD 4.90 and USD 5.20 each. The cost was higher than their average food expenditure (USD 2.90), indicating that students in the university have to spend more money on food sold at the university cafeteria to fulfill their nutrient recommendation. Hence, relevant authorities should take appropriate initiatives so that the food insecurity problem among low income university students can be managed to improve their quality of life and nutritional status.
\end{abstract}

Keywords: food insecurity, linear programming, nutritional status, quality of life, university student

\section{INTRODUCTION}

Food insecurity has long been a global issue which taking place in both developed and developing countries (Gundersen 2013). It occurs when there is limited or uncertain ability to obtain safe and nutritionally adequate food in socially acceptable manner. According to the United State Department of Agriculture, there are four level of food security status: high food security, marginal food security, low food security, and very low food security (USDA 2018).

University students are vulnerable to food insecurity due to their socioeconomic and demographic status (Hashim et al. 2014). Most of them face financial constraints as they lack of stable financial resources. As a result, they rely upon financial aid, loan or scholarship to pay the university fees (Broton \& Goldrick-
Rab 2016). Moreover, the increase in education cost and cost of living becomes a burden and affect their spending habit (Saruchi et al. 2015). Although loans are provided, the excess fund after deducting school and accommodation fees is insufficient to support student life in campus (Nisha 2017). This consequently causes food insecurity among university student especially those come from low income household (Munro et al. 2013). In Malaysia, low income refers to the bottom $40 \%$, or B40, of the households with monthly income of USD 1053 (RM4360) and below (Khazanah Research Institute 2018).

Food insecurity negatively affects the diet quantity, quality, and hence the individual nutritional status. It contributes to malnutrition such as obesity, micronutrient deficiency, children wasting and stunting (FAO 2018). In university, most students practice unhealthy eating patterns

\footnotetext{
"Corresponding Author: tel: +603-92897511, email: roslee@ukm.edu.my
} 
as coping strategy to reduce food expenditure. For example, they choose less expensive but non-nutritious foods such as instant noodles and reduced the number of meals a day (Rudolph et al. 2018). As the consequences, study showed that food insecure students have lower vegetables and fruits intake, lower micronutrients than those with high food security (Gallegos et al. 2014).

Food insecurity affects quality of life of individuals. Previous studies revealed that there is significant correlation between food security status and quality of life (Gholami et al. 2017; Chung et al. 2016; Moafi et al. 2018). However, most studies only focus on women, elderly, and patients. Yet, there is limited study being carried out among university students specifically for those from low income household in Malaysia. Hence, this study aims to determine the prevalence of food insecurity among low income students in university. The association of food insecurity with quality of life and nutritional status among low income students was also investigated. A diet optimization model was developed to find out the minimum cost required to fulfill all nutrient requirements.

\section{METHODS}

\section{Design, location, and time}

A total number of 108 low income students from a public university in Selangor, Malaysia participated in this cross-sectional study. Subjects were selected from the list of students that receiving welfare allowances from the university and approached randomly at the cafeteria using convenient sampling method. This study was conducted at the main campus of a public university in Selangor. The inclusion criteria were subjects had to be more than 18 years of age, a Malaysian, a healthy individual, and came from a family with monthly income less than USD 1,053. The data was collected from February 2019 until May 2019.

\section{Sampling}

Sample size were calculated using the Slovin (1967) formula, where the population size (N) is 2,200 students and the degree of accuracy (e) is 0.1 . Thus, the number of minimum samples for low income students at the Universiti Kebangsaan Malaysia (UKM) is 95 students.

Considering the possibility of subjects withdrawing from this study, the number of subjects were increased by $10 \%$. A total of 105 students were recruited to enable this study to reach $90 \%$ confidence level.

\section{Data collection}

The data collection was in the form of interview-based questionnaire. The data included were social demography, anthropometry, food security status, quality of life and dietary intake. The World Health Organization Quality of LifeBrief (WHOQOL-BREF) questionnaire was used to assess the quality of life while the USDA Sixitem Short Form of Survey Module was used for food security status. Both was in validated Malay version. Next, the dietary intake was assessed by using diet history method. Based on the subjects eating pattern information, the price list of food was also obtained from the cafeteria of four different colleges at the university. Ethical approval was obtained from the National University of Malaysia's Research Committee (UKM1.21.3/244/NN-2019-050) on 11th March 2019.

\section{Data analysis}

Descriptive and inferential data analyses were carried out by using Statistical Package for Social Sciences (SPSS) version 25.0. For inferential data analysis, normality test was carried out by using Kolmogorov-Smirnov. Chi Square test was used to identify the relationship between quality of life and food security status while Spearman Rho test was used to analyze the correlation between nutritional status and food security. Nutritionist Pro-software was used to analyze dietary intake prior to analysis by SPSS.

Linear programming model was utilized to develop the optimal diet which fulfill the students' nutrient recommendations at the lowest cost. First, input data for the diet optimization model was obtained from the dietary records of the students by using diet history assessment. A total of 104 cooked food items which had been usually consumed by the students in UKM café were used. All food items were categorized into food subgroups based on nutritional similarity and culinary usage. The subgroups included cooked set meals, grains, meat and alternatives, vegetables, milk and dairy products, fruits and miscellaneous food items. The model used in LP was specified as follows:

$$
\begin{aligned}
& \operatorname{Min} p=\sum c_{j} x_{j} \\
& \text { Subject to: } l_{i} \leq \sum_{i j} a_{i j} \leq u_{i} \\
& x_{j} \geq 0, x_{j} \in \mathbb{Z}
\end{aligned}
$$

The objective of the model was to minimize food cost, $p$ (in RM). The portion size of food item $j$ is represented as $\mathrm{x}_{j}$; $\mathrm{a}_{i}$ denotes the amount of nutrient $i$ in one portion of food item 
$j$; $\mathrm{c}_{j}$ is the cost of one portion of food item $j ; 1_{i}$ and $u_{i}$ denote the smallest and largest acceptable quantity of nutrient $i$ respectively and the last constraint specifies that the portion size, $\mathrm{x}_{j}$ to be integer value (Rajikan et al. 2017).

To provide practical and palatable menu, a set of constraints were introduced to the linear programming models. The lower and upper limits of all the nutrients were set based on Recommended Nutrients Intake (RNI 2017). Besides, the upper and lower limit on portion size for each food item and food group were set according to Malaysian Dietary Guidelines (MDG 2010) and the common intake pattern of students to ensure that the suggested menus were suitable for them.

Microsoft Excel in addition with OpenSolver plug in which has been developed by Mason (2012) was utilized for the diet optimization modelling. The constraints were placed together with prices and nutrient composition of each food item in the LP model. Once the software was run, the minimum cost and the selected food items were considered as a diet model for daily consumption (Chung et al. 2016).

\section{RESULTS AND DISCUSSION}

\section{Sociodemographic characteristics and food security status}

In this study, a total of 108 low income students $(57.8 \%$ female, $47.2 \%$ male) completed the questionnaire. Majority of them were Malay $(74.1 \%)$, followed by Chinese $(13 \%)$, Indian $(12 \%)$ and others $(0.9 \%)$. The students' age ranged from 19 to 26 , with a mean age of $22 \pm 1.42$. Majority of students $(52.8 \%)$ came from low income family, which was USD 237 to USD 631 per month while the rest from poor family with income USD 237 and below per month. More than half of students $(57.4 \%)$ received education loan funds and only $10.2 \%$ without any loan or scholarship. The average daily food expenditure was USD 2.90 and in academic performance, they scored CGPA 3.40 on average.

Table 1 presented the prevalence of food insecurity among students. High or marginal food security was categorized as food secure while low and very low food security were categorized as food insecure (USDA 2018). Majority of low income students $(69.4 \%)$ were food insecure with half of them $(50 \%)$ reported low food security and $29.4 \%$ with very low food security.
This result was almost similar to the study by Sulaiman et al. 2013 which revealed that $67.1 \%$ of students from four public universities in Malaysia who receiving financial assistance experienced some kind of food insecurity. However, in contrast with this result, study by (Ramlee et al. 2019) demonstrated a much lower food insecurity prevalence, which was only $22 \%$ among university student in Terengganu. According to the Department of Statistics, prices and living cost vary significantly across different states in Malaysia. The price for food and nonalcoholic beverages in the highly urbanized states (Selangor) was typically higher and increase at a faster rate than the less urbanized states such as Terengganu (Mahidin 2019). The increase of food price will affect the ability of individuals to get assess to food (Lee et al. 2013).

There was no significant association between food security status with ethnic, age, family income, financial assistance, CGPA and food expenditure (Table 2). Male students were more likely to be food insecure than female. This finding was similar to the results from McArthur et al. (2018) and Soldavini et al. (2019). Males have higher standard body weight and metabolic rate hence usually need higher energy consumption than females. Thus, males tend to take larger quantity of food to fulfill their hunger (Chan 2013). The gender perspective is related to food insecurity (Thakur 2016).

There was no significant association between food security status with other socioeconomic factors included age, ethnic, family income, financial assistance and CGPA. This was similar to a study on university students by Ramlee et al. (2019). However, study by Hagedorn (2018) showed that GPA of food insecure students was significantly lower than food secure students $(\mathrm{p}<0.0001)$. Also, in terms of financial assistance, students who had a scholarship were more food secure with a significant difference (Mansour 2014). These contradictions might be due to the different demographic profiles of students.

Table 1 . Food insecurity prevalence among low income students

\begin{tabular}{lcc}
\hline $\begin{array}{c}\text { Food security } \\
\text { status }\end{array}$ & $\begin{array}{c}\text { Frequency } \\
(\mathrm{n}=108)\end{array}$ & $\begin{array}{c}\text { Percentage } \\
(\%)\end{array}$ \\
\hline High or marginal & 33 & 30.6 \\
Low & 54 & 50.0 \\
Very low & 21 & 29.4 \\
\hline
\end{tabular}


Table 2. Association between sociodemographic characteristics and food security status

\begin{tabular}{|c|c|c|c|c|c|}
\hline \multirow{3}{*}{$\begin{array}{l}\text { Sociodemographic } \\
\text { characteristics }\end{array}$} & \multicolumn{4}{|c|}{ Food security } & \multirow{3}{*}{$\mathrm{p}$} \\
\hline & \multicolumn{2}{|c|}{$\begin{array}{l}\text { Secure } \\
(n=33)\end{array}$} & \multicolumn{2}{|c|}{$\begin{array}{l}\text { Insecure } \\
(\mathrm{n}=75)\end{array}$} & \\
\hline & $\mathrm{n}$ & $\%$ & $\mathrm{n}$ & $\%$ & \\
\hline \multicolumn{6}{|l|}{ Gender } \\
\hline Male $(\mathrm{n}=51)$ & 10 & 30.3 & 41 & 54.67 & \multirow{2}{*}{$* 0.019^{\mathrm{a}}$} \\
\hline Female $(n=57)$ & 23 & 69.7 & 34 & 45.33 & \\
\hline \multicolumn{6}{|l|}{ Ethnic } \\
\hline Malay $(\mathrm{n}=80)$ & 23 & 69.70 & 57 & 76 & \multirow{4}{*}{$0.772^{\mathrm{a}}$} \\
\hline Chinese $(n=14)$ & 5 & 15.15 & 8 & 10.67 & \\
\hline Indian $(n=13)$ & 5 & 15.15 & 9 & 12 & \\
\hline Others $(\mathrm{n}=1)$ & 0 & 0 & 1 & 1.33 & \\
\hline \multicolumn{6}{|l|}{ Family income ${ }^{* *}$} \\
\hline Poor $(\mathrm{n}=19)$ & 4 & 12.12 & 15 & 20 & \multirow{3}{*}{$0.461^{\mathrm{a}}$} \\
\hline Low income (n=57) & 17 & 51.52 & 40 & 53.33 & \\
\hline Middle low income $(\mathrm{n}=32)$ & 12 & 36.36 & 20 & 26.67 & \\
\hline \multicolumn{6}{|l|}{ Financial assistance } \\
\hline Yes $(n=11)$ & 2 & & 9 & & \multirow[t]{2}{*}{$0.498^{\mathrm{a}}$} \\
\hline No $(n=97)$ & 31 & & 66 & & \\
\hline Mean of CGPA & 3.46 & & 3.36 & & $0.152^{\mathrm{b}}$ \\
\hline Daily food expenditure & USD 2.80 & & USD 2.70 & & $0.668^{\mathrm{b}}$ \\
\hline
\end{tabular}

\section{Food security and quality of life}

As shown in Table 3, majority of the low income students have a good quality of life in the aspect of physical health, psychological, social relationship and environment. The score range for each domain was from 0-100 with the higher the score, the better the quality of life. A previous local study stated that the quality of life students experience in a university increases when they believe their needs are aligned with the goals of the university because they perceive that the university is responsive to their needs (Haron et al. 2015). The domain with the highest mean score was social relationship at $68.60 \pm 14.53$. This was probably because university is a community that has unified goals and values; traditions and symbols of belonging, mutuality of support, encourage participation and create a positive human learning environment (Strange \& Banning 2001). The lowest mean score was $53.87 \pm 10.42$ for physical health domain. Since students did not have much time to sleep, rest, and leisure activities due to spending more time for studying and doing their research works, then this problem can affect physical health domain (Vakili et al. 2012).

There was no significant association between quality of life and food security status (Table 4). However, based on the findings, the food insecure students have slightly lower mean score for the domain of physical health, social relationship, and environment compared to food secure students. This was consistent with previous study that reported food insecure and at-risk students were more likely to report their overall health as fair, poor, or very poor and reported lower energy levels compared with food secure students (Payne-Sturges et al. 2018). Food insecurity compromises students's health, diet, and academic quality (Farahbakhsh et al. 2017).

\section{Food security and nutritional status}

In this study, majority of students (59.3\%) had normal Body Mass Index (BMI), followed by $20.4 \%$ were overweight, $10.4 \%$ were obese, and $10.2 \%$ were underweight. Table 5 showed the energy and nutrient intake of students by gender. Majority of male and female students 
Table 3. Quality of life among low incomes students using WHOQOL-BREF

\begin{tabular}{lc}
\hline \multicolumn{1}{c}{ Domain quality of life } & Mean \pm SD \\
\hline Physical health & $53.87 \pm 10.42$ \\
Psychological & $65.12 \pm 10.22$ \\
Social relationship & $68.60 \pm 14.53$ \\
Environment & $66.87 \pm 12.02$ \\
\hline
\end{tabular}

Table 4. Association between food security status and quality of life

\begin{tabular}{|c|c|c|c|}
\hline \multirow{3}{*}{ Quality of life } & \multicolumn{2}{|c|}{ Food security status } & \multirow{3}{*}{$\mathrm{p}^{*}$} \\
\hline & Secure & Insecure & \\
\hline & Mean \pm SD & Mean \pm SD & \\
\hline $\begin{array}{l}\text { Physical } \\
\text { health }\end{array}$ & $55.09 \pm 9.02$ & 0.99 & 0.344 \\
\hline Psychological & $64.65 \pm 10.21$ & $65.33 \pm 10.28$ & 0.671 \\
\hline $\begin{array}{l}\text { Social } \\
\text { relationship }\end{array}$ & $70.96 \pm 11.62$ & $67.56 \pm 15.59$ & 0.851 \\
\hline Environment & $67.99 \pm 10.83$ & $66.38 \pm 12.55$ & 0.339 \\
\hline
\end{tabular}

*Chi-square test

failed to meet the RNI for energy. This result was consistent to the study on university students from 4 selected universities in Selangor, Malaysia which revealed that $90.9 \%$ of males and $72.2 \%$ of females had energy intake below RNI (Abdull Hakim et al. 2012). Previous study also showed that majority of university students $(73.0 \%$ males and $80.5 \%$ females) did not meet RNI for energy (Gan et al. 2011). In this study, most of the students exceed the RNI for fat $(56.87 \%$ males and $49.12 \%$ females). This finding was consistent to previous study that showed majority of the student had exceeded their fat intake with the percentage of $41.5 \%(n=37)$ of male student and $56.5 \%(\mathrm{n}=62)$ of female student (Abdull Hakim et al. 2012). There was no significant correlation between energy and macronutrient with food security status $(p=0.68)$. This was probably because of the limited variety of food option available in university cafeteria, resulting in non-significant difference in all students' eating pattern. According to the diet history collected, there were similarities in food choice among the students. High energy food source is inexpensive thus will likely influence food insecure adults who would anticipate future food scarcity by over consuming when food is available (Seligman \& Schillinger, 2010). However, micronutrient rich food which is usually more expensive (Maillot et al. 2007; Ekaningrum et al. 2017) will be affected by food security status and daily food expenditure. There were no significant differences of mean BMI between food secure and food-insecure students $(p=0.264)$. This result was consistent with the findings by Hagedorn and Melissa (2018).

\section{Optimum diet model}

This study found out that majority of the students were unable to fulfil their daily nutrient intake due to financial constraints. A previous study showed that food prices was one of the main reasons in food selection among undergraduate students in Indonesia (Puspadewi \& Briawan 2015). In order to help them overcome their inadequate nutrient intake (Huang et al. 2003; Moy et al. 2009), palatable and healthy menus based on the cooked food choices they usually consumed have been developed at the lowest cost by using Linear Programming as shown in Table 6. Diet optimization models were chosen as an intervention because it is a flexible approach in translating nutrient recommendations to realistic food choices (Buttriss et al. 2014).

All the constraints for nutrient were set according to lower and upper limit intake from RNI 2017 except for potassium which follows the guidelines from World Health Organization for adults which is $3,510 \mathrm{mg} /$ day (WHO 2012). This was because potassium was the limiting nutrient and the recommendation based on RNI 2017 were slightly high which is $4,700 \mathrm{mg} /$ day and it was quite impossible and very difficult to achieve as the food choices high in potassium were also limited.

Using the linear programming model, we mathematically obtained a gender specific optimized food intake models that achieved a set of 19 nutrient recommendations given in the RNI 2017 for Malaysian adults. It was found that vitamin $A$, vitamin $C$, niacin, and riboflavin were in moderately acceptable limits while potassium, fiber, and mono-saturated fat only reached the lower limit of the constraint values for both genders. The other limiting nutrient was iron for female only. The prices of the menu produced by the model were USD 4.90 and USD 5.20 for male and female respectively.

Thus, in order for the students to fulfil all their nutritional requirements, they need to make several changes to their usual daily intake such as increasing fruits and vegetables intake. This result was consistent with previous study that demonstrated for younger age groups, meeting nutritional goals requires a drastic increase in 
Table 5. Energy and nutrient intakes by gender

\begin{tabular}{|c|c|c|c|c|}
\hline Nutriants & Male $(n=51)$ & Female $(n=57)$ & Male $(n=51)$ & Female $(n=57)$ \\
\hline Nutrients & $\mathrm{n}(\%)$ & $\mathrm{n}(\%)$ & Mean \pm SD & Mean \pm SD \\
\hline Energy (kcal) & & & $1594.63 \pm 496.78$ & $1126.70 \pm 332.12$ \\
\hline$\%$ RNI & & & $81.36 \pm 25.35$ & $69.98 \pm 20.63$ \\
\hline$<$ RNI & $40(78.43)$ & $51(89.47)$ & & \\
\hline$\geq \mathrm{RNI}$ & $11(21.57)$ & $6(10.53)$ & & \\
\hline Carbohydrate (g) & & & $222.07 \pm 65.97$ & $154.70 \pm 49.90$ \\
\hline Protein $(g)$ & & & $52.38 \pm 22.34$ & $40.90 \pm 16.35$ \\
\hline$\%$ RNI & & & $84.48 \pm 36.06$ & $77.18 \pm 30.84$ \\
\hline$<$ RNI & $40(78.43)$ & $45(78.95)$ & & \\
\hline$\geq \mathrm{RNI}$ & $11(21.57)$ & $12(21.05)$ & & \\
\hline Fat $(\mathrm{g})$ & & & $58.92 \pm 26.42$ & $40.68 \pm 19.05$ \\
\hline Energy from carbohydrate (\%) & & & $56.47 \pm 7.53$ & $55.31 \pm 9.32$ \\
\hline$<50 \%$ & $9(17.65)$ & $13(22.81)$ & & \\
\hline $50-65 \%$ & $37(72.55)$ & $34(59.65)$ & & \\
\hline$>65 \%$ & $5(9.8)$ & $10(17.54)$ & & \\
\hline Energy from protein (\%) & & & $13.06 \pm 3.40$ & $14.50 \pm 3.81$ \\
\hline$<10 \%$ & $4(7.84)$ & $6(10.53)$ & & \\
\hline $10-15 \%$ & $37(72.55)$ & $27(47.37)$ & & \\
\hline$>15 \%$ & $10(19.61)$ & $24(42.10)$ & & \\
\hline Energy from fat $(\%)$ & & & $32.37 \pm 6.68$ & $31.94 \pm 10.19$ \\
\hline$<25 \%$ & $6(11.76)$ & $11(19.30)$ & & \\
\hline $25-30 \%$ & $16(31.37)$ & $18(31.58)$ & & \\
\hline$>30 \%$ & $29(56.87)$ & $28(49.12)$ & & \\
\hline
\end{tabular}

RNI: Recommended Nutrient Intake; SD: Standar Deviation

consumption of specific food groups and food subgroups such as green and yellow vegetables, other vegetables and fruit for both genders (Okubo et al.2015). Moreover, the models produced daily total food cost that was higher than the students' average daily expenditure on food. This showed that students need to spend more on the foods that are available at the cafeteria in order to fulfil all the nutrient requirements.

Although this study was an exploratory study that aimed to examine the prevalence of food insecurity and its association with quality of life and nutritional status among low income students, convenience sampling made the results unlikely to be conclusive. Likewise, the same conclusion could be drawn with regard to the absence of relationship between food security, quality of life, and nutritional status. Convenience sampling also limits the generalizability of the study findings across populations. However, volunteer bias was reduced by focusing only on low income students. Nevertheless, the study highlighted the need for an on-going monitoring of food insecurity status among low income students. Introduction of intervention and prevention measures should be carefully considered by the relevant authorities to ensure that availability and affordability of healthy foods around university campus could be improved. Future studies should consider longitudinal study and random sampling so that causal relationships can be established as well as enhancing the generalizability of the findings.

The other limitation of this study was it may have underreported nutritional intake of the students as some of them could not recall clearly what they have eaten during the interview session. For linear programming, in order to make the optimal diet models reasonably palatable, careful considerations on setting the right constraints in the models has to be done to avoid infeasibility of the models. Addition of more variety of foods will provide more options to be chosen as well as improving palatability of the suggested diet model. However, the inclusion of the food items in the model would depend on the availability of the foods item within campus vicinity. 
Table 6 Optimum menu developed by using linear programming

\begin{tabular}{|c|c|c|}
\hline Meals & Model 1 (male) & Model 2 (female) \\
\hline Breakfast & $\begin{array}{l}2 \text { slices of whole meal bread } \\
1 \text { cup of rolled oats } \\
1 \text { dessert spoon of non-dairy creamer }\end{array}$ & $\begin{array}{l}1 \text { cup of rolled oats } \\
1 \text { dessert spoon of non-dairy creamer }\end{array}$ \\
\hline Morning tea & $\begin{array}{l}1 \text { glass of chocolate milk } \\
1 \text { piece of cream filled bread }\end{array}$ & $\begin{array}{l}1 \text { tub of plain yoghurt } \\
1 \text { slice of honeydew }\end{array}$ \\
\hline Lunch & $\begin{array}{l}3 \text { scoops of rice } \\
1 \text { piece of chicken soup } \\
1 \text { cup of fried spinach } \\
1 \text { banana }\end{array}$ & $\begin{array}{l}3 \text { scoops of rice } \\
1 \text { piece of chicken soup } \\
1 \text { cup of fried spinach and okra }\end{array}$ \\
\hline Afternoon tea & $\begin{array}{l}1 \text { piece of curry puff } \\
1 \text { cup of coffee }\end{array}$ & $1 / 2$ whole guava \\
\hline Dinner & $\begin{array}{l}1 \text { plate of fried kueh teow } \\
1 / 2 \text { cup of fried green mustard leaves } \\
1 / 2 \text { whole guava }\end{array}$ & $\begin{array}{l}1 \text { plate of nasi goreng USA } \\
\text { (1 plate fried rice } \\
1 \text { small bowl beef in spicy tomato sauce } \\
1 \text { fried egg) } \\
1 \text { glass of iced milo }\end{array}$ \\
\hline Supper & $\begin{array}{l}1 \text { chocolate flavoured drink }+1 \text { dessert } \\
\text { spoon of non-dairy creamer }\end{array}$ & $\begin{array}{l}1 \text { chocolate flavoured drink }+1 \text { dessert } \\
\text { spoon of non-dairy creamer }\end{array}$ \\
\hline $\begin{array}{l}\text { Price of whole menu } \\
\text { (USD) }\end{array}$ & 4.90 & 5.20 \\
\hline Energy (kcal) & 1990 & 1796 \\
\hline Protein (g) & 63.64 & 60.65 \\
\hline Carbohydrate (g) & 292.42 & 266.26 \\
\hline Fat $(g)$ & 65.11 & 56.47 \\
\hline $\begin{array}{l}\text { Fiber }(\mathrm{g}) \\
(20-30 \mathrm{~g} / \text { day* })\end{array}$ & 20.08 & 20 \\
\hline $\begin{array}{l}\text { Calcium (mg) } \\
(1000 \mathrm{mg} / \text { day*) }\end{array}$ & $1,176.37$ & $1,012.03$ \\
\hline $\begin{array}{l}\text { Phosphorus (mg) } \\
\text { (700 mg/day*) }\end{array}$ & $1,317.88$ & $1,235.16$ \\
\hline $\begin{array}{l}\text { Iron }(\mathrm{mg}) \\
\left(14-29 \mathrm{mg} / \text { day*}^{*}\right)\end{array}$ & 21.36 & 21.27 \\
\hline $\begin{array}{l}\text { Sodium (mg) } \\
\left(1500 \mathrm{mg} / \text { day*}^{*}\right)\end{array}$ & $2,140.26$ & $1,797.69$ \\
\hline $\begin{array}{l}\text { Potassium (mg) } \\
\left(4700 \mathrm{mg} / \text { day* }^{*}\right)\end{array}$ & $2,522.39$ & $3,514.24$ \\
\hline $\begin{array}{l}\text { Vitamin A ( } \mu \mathrm{g} \mathrm{RE}) \\
(600 \mu \mathrm{g} \mathrm{RE} / \text { day*) }\end{array}$ & $1,273.52$ & $1,623.93$ \\
\hline $\begin{array}{l}\text { Thiamin }(\mathrm{mg}) \\
\left(1.1-1.2 \mathrm{mg} / \text { day* }^{*}\right)\end{array}$ & 1.28 & 1.15 \\
\hline $\begin{array}{l}\text { Riboflavin (mg) } \\
(1.1-1.3 \mathrm{mg} / \text { day*) }\end{array}$ & 1.91 & 1.49 \\
\hline $\begin{array}{l}\text { Niacin }(\mathrm{mg}) \\
\left(14-16 \mathrm{mg} / \text { day}^{*}\right)\end{array}$ & 23.18 & 20.80 \\
\hline $\begin{array}{l}\text { Vitamin C (mg) } \\
\left(70 \mathrm{mg} / \text { day }^{*}\right)\end{array}$ & 355.54 & 401.74 \\
\hline
\end{tabular}
$\left(70 \mathrm{mg} /\right.$ day* $\left.^{*}\right)$

*Based on Recommended Nutrient Intake 2017 
Rajikan et al.

\section{CONCLUSION}

The prevalence of food insecurity among low income students in the selected public university in Selangor was high at $69.4 \%$ and male students reported higher food insecurity compared to female students. However, there was no significant association between food insecurity and quality of life of the students. There was also no significant correlation between nutritional status and food security. This study concluded that a nutritionally complete meal was not affordable and expensive towards the low income students. Hence, it is very crucial for university related authorities to take other alternatives such as provision of cheaper yet nutritious food, food stamps or food subsidies given towards this particular group of students in order to help them achieve their nutritional requirement. Furthermore, cafes in universities or colleges should provide wider food choices that are healthy and nutritionally balanced that are affordable for the students. Governmental and university-based programs and policies are needed to improve the food security situation of university students (Farahbakhsh et al. 2017).

\section{ACKNOWLEDGEMENT}

The authors would like to thank all the subjects who participated in this study. We would also like to express our gratitude to Ministry of Higher Education Malaysia which provided grant FRGS/1/2018/SS08/USIM/02/6 to conduct this research. The authors has no conflict of interest.

\section{REFERENCES}

Abdull Hakim NH, Muniandy ND, Ajau Danish. 2012. Nutritional status and eating practices among university students in selected universities in Selangor, Malaysia. Asian J Clin Nutr 4(3):77-87.

Broton K, Goldrick-Rab S. 2016. The dark side of college (Un) affordability: Food and housing insecurity in higher education. change. The Magazine of Higher Learning 48(1):16-25.

Buttriss JL, Briend A, Darmon N, Ferguson EL, Maillot M, Lluch A. 2014. Diet modelling: How it can inform the development of dietary recommendations and public health policy. Nutrition bulletin 39(1):115-125.
Chan SW. 2013. Gender differences in eating behaviour. International Journal of Accounting \& Business Management 4(2):116-121.

Chung HK, Kim OY, Kwak SY, Cho Y, Lee KW, Shin MJ. 2016. Household food insecurity is associated with adverse mental health indicators and lower quality of life among Koreans: Results from the Korea National Health and Nutrition Examination Survey 2012-2013. Nutrients 8(12):819.

Ekaningrum AY, Sukandar D, Martianto D. 2017. Keterkaitan densitas gizi, harga pangan, dan status gizi pada anak Sekolah Dasar Negeri (SDN) Pekayon 16 Pagi. J Gizi Pangan 12(2):139-146.

FAO I, UNICEF, WFP, WHO. 2018. The state of food security and nutrition in the world 2018. Building Climate Resilience for Food Security and Nutrition. FAO. Rome.

Farahbakhsh J, Hanbazaza M, Ball GDC, Farmer AP, Maximova K, Willows ND. 2017. Food insecure student clients of a universitybased food bank have compromised health, dietary intake and academic quality. Nutrition \& dietetics 74(1):67-73.

Gallegos D, Ramsey R, Ong KW. 2014. Food insecurity: Is it an issue among tertiary students? Higher Education 67(5):497510.

Gan WY, Mohd T, Mohd Shariff Z, Abu Saad H. 2011. Differences in eating behaviours, dietary intake and body weight status between male and female Malaysian university students. Malaysian Journal of Nutrition 17(2):213-228.

Gholami A, Khazaee-Pool M, Rezaei N, Amirkalali B, Moradpour F, Rajabi A, Sohrabi M, Yarmohammadi R, Z Mousavi J. 2017. Household food insecurity is associated with health-related quality of life in rural type 2 diabetic patients. Archives of Iranian Medicine 20(6):350 355. doi: 0172006/AIM.006.

Gundersen C. 2013. Food insecurity is an ongoing national concern. Advances in Nutrition 4(1):36-41.

Hagedorn RLO, Melissa D. 2018. Food insecurity and behavioral characteristics for academic success in young adults attending an Appalachian University. Nutrients 10(3):361.

Haron H, Osman BM, Maidinsah H, Sari MMM, Zaki NQM. 2015. Determinants of qua- 
lity of life (qol) and quality of university life (qul) in Malaysian public university students. AIP Conference Proceedings 505-511.

Hashim N, Isa KAM, Dahlan A, Ismail NH. 2014. Exploring the understanding of hunger experience among Malay undergraduate students in Malaysia. Recent Trends in Social and Behaviour Sciences: Proceedings of the 2nd International Congress on Interdisciplinary Behavior and Social Science, ICIBSoS 2013. 549552.

Huang TTK, Harris KJ, Lee RE, Nazir N, Born W, Kaur H. 2003. Assessing overweight, obesity, diet, and physical activity in college students. J Am Coll Health 52(2):83-86.

Khazanah Research Institute. 2018. The State Of Households 2018: Different Realities 3rd Edition. Khazanah Research Institute.

Lee A, Mhurchu CN, Sacks G, Swinburn B, Snowdon W, Vandevijvere S, Hawkes C, L'abbe M, Rayner M, Sanders D, et al. 2013. Monitoring the price and affordability of foods and diets globally. Obes Rev 14(1):82-95.

Mahidin DSDMU. 2019. Consumer Price Index Malaysia April 2019. Malaysia: Department of Statistics Malaysia.

Maillot M, Darmon N, Darmon M, Lafay L, Drewnowski A. 2007. Nutrient-dense food groups have high energy costs: an econometric approach to nutrient profiling. J Nutr 137(7):1815-1820.

Mansour R. 2014. Food Security among Students at University of Wollongong. Doctor of Philosophy thesis, School of Health and Society, University of Wollongong. http:// ro.uow.edu.au/theses/4337.

Mason AJ. 2012. Opensolver-an Open Source Add-in to Solve Linear and Integer Progammes in Excel. Operations Research Proceedings 2011. Springer 401-406.

McArthur LH, Ball L, Danek AC, Holbert D. 2018. A high prevalence of food insecurity among university students in Appalachia reflects a need for educational interventions and policy advocacy. J Nutr Educ Behav 50(6):564-572.

Moy F, Surin J, Ismail Y, Mahad R, Tie F, Wan Ismail W. 2009. Breakfast skipping and its associated factors among undergraduates in a public university in Kuala Lumpur. Malays J Nutr 15(2):165-174.
Munro N, Quayle M, Simspon H, Barnsley S. 2013. Hunger for knowledge: Food insecurity among students at the University of Kwazulu-Natal. Perspectives in Education 31(4):168-179.

Nisha FKA. 2017. Tingkah laku mahasiswa dalam menguruskan wang pembiayaan pendidikan. Malaysia: Proceeding of the 4th International Conference on Management and Muamalah 2017.

Okubo H, Sasaki S, Murakami K, Yokoyama T, Hirota N, Notsu A, Fukui 1M, Date C. 2015. Designing optimal food intake patterns to achieve nutritional goals for Japanese adults through the use of linear programming optimization models. Nutr J 14(1):57.

Payne-Sturges DC, Tjaden A, Caldeira KM, Vincent KB, Arria AM. 2018. Student hunger on campus: food insecurity among college students and implications for academic institutions. Am J Health Promot 32(2):349-354.

Puspadewi RH, Briawan D. 2015. Persepsi tentang pangan sehat, alasan pemilihan pangan dan kebiasaan makan sehat pada mahasiswa. J Gizi Pangan 9(3):211-218.

Rajikan R, Zaidi NIA, Elias SM, Shahar S, Manaf ZA, Yusoff NaM. 2017. Construction of healthy and palatable diet for low socioeconomic female adults using linear programming. Int $\mathrm{J}$ Adv Sci Eng Inf Technol 7(1):125-131.

Rudolph M, Kroll F, Muchesa E, Manderson A, Berry M, Richard N. 2018. Food insecurity and coping strategies amongst students at University of Witwatersrand. J Food Secur 6(1):20-25.

Saruchi S, Abdul-Rahman A, Wahid H. 2015. Pola perbelanjaan dan haddul kifayah zakat bagi pelajar sarjana muda di UKM. Jurnal Personalia Pelajar 18(2):33-44.

Seligman HK, Schillinger D. 2010. Hunger and socioeconomic disparities in chronic disease. N Engl J Med 363(1):6-9.

Soldavini J, Berner M, Da-Silva J. 2019. Rates of and characteristics associated with food insecurity differ among undergraduate and graduate students ata large public university in the southeast United States. Preventive Medicine Reports 14(100836):2-8.

Strange CC, Banning JH. 2001. Educating by Design: Creating Campus Learning Environments That Work. The Jossey-Bass Higher and Adult Education Series. ERIC. 
Sulaiman N, Md. Jusoh Z, Ab Razak M. 2013. Food insecurity among public university students receiving financial assistance in peninsular Malaysia. Malaysian J Consum Fam Econ 16:78-90.

Ramlee IS, Ali A, Zalbahar N, Wahab RA, Jaafar SNA. 2019. Food insecurity among university students at two selected public universities in Malaysia. Malaysian Applied Biology 48(1):101-110.

Thakur R. 2016. Gendered Perspectives on Food Insecurity in Saskatoon. University of Saskatchewan.
[USDA] United States Department of Agriculture. 2018. Definitions of Food Security. United States Department of Agriculture Economic Research Service.

Vakili Z, Mohamad AR, Vakili MA. 2012. A quantitative study of quality of life (Qol) on postgraduate students in Universiti Sains Malaysia. Casp J Appl Sci Res 1(7):28-32.

[WHO] World Health Organization. 2012. Guideline: Potassium Intake for Adults and Children.World Health Organization. 